\title{
Russia-Ukraine War Is Not a Simple Riddle
}

\author{
Jokull Johannesson \\ Institute of Strategy and Leadership, University of Agder, Kristiansand, Norway \\ Email: jokull.johannes son@uia.no
}

How to cite this paper: Johannesson, J. (2017) Russia-Ukraine War Is Not a Simple Riddle. Open Journal of Social Sciences, 5 , 139-147.

https://doi.org/10.4236/jss.2017.510013

Received: August 28, 2017

Accepted: October 15, 2017

Published: October 18, 2017

Copyright $\odot 2017$ by author and Scientific Research Publishing Inc. This work is licensed under the Creative Commons Attribution International License (CC BY 4.0).

http://creativecommons.org/licenses/by/4.0/

\begin{abstract}
The Russia-Ukraine conflict is the most serious test of European security in the 21 st century and the forgone conclusion is that Russia can easily prevail in the conflict, but this has not been the case. This article uses a contingency theory approach to report findings on the riddle why Russia has not easily defeated Ukraine. I report findings based on a contingency theoretical perspective that indicates Russian victory is unlikely because of negative contingencies having direct impact on the Russian economy including a sharp reduction in the value of the Russian ruble, the potential for political loss of support of the middle class for President Putin, diplomatic and political isolation and danger of escalation of the war, affecting Russia to a greater degree than the Ukraine.
\end{abstract}

\section{Keywords}

Russia, Ukraine, Contingency Theory, War, Conflict, Global Affairs, Riddle

\section{Introduction}

President Putin allegedly stated: "If I wanted, Russian troops could not only be in Kiev in two days, but in Riga, Vilnius, Tallinn, Warsaw or Bucharest, too" [1]. So, the big question is, why isn't he? The purpose of this article is to shed some light on this riddle by analyzing the contingency factors affecting Russia and Ukraine and discuss the consequences for the two countries. This article argues that contingency factors limit the options and freedom of action for the Russian government in a total war with Ukraine. Particularly, the Russian government needs to take into consideration the impact the Ukraine conflict has and will have on all aspects of life in the Russian Federation; these consequences are many. First is the direct impact on the economy as consequences of the sanctions imposed by, primarily, the United States and the European Union. The Russian ruble has taken a hit in the currency markets, capital flight is rampant 
and shortage of certain consumer goods is nibbling at the political support of the middle class for President Putin. Second, the Russian government faces an increasing diplomatic and political isolation which is detrimental to its status as a world player and hurts President Putin's personal status and reputation internally and globally and, the new round of USA sanctions by the President Trump administration further isolates Russia. Third, there is the ever-present danger of escalation of the war between Russia and Ukraine by use of weapons of mass destruction and plausible intervention by other countries. Forth, Russia commitment to Syria and plausibility of a war on the Korean peninsula further limits Russia's resources available to wage war with Ukraine.

Similarly, the contingency factors impact Ukraine and the Ukraine government, much of it negatively. The economy has slipped into a recession, the Ukraine currency has fallen by as much as half, large sections of its key energy and industrial areas have come under Russian control, internal refugees put a severe strain on the social security system and the loss of Donbass industry and Crimea shrank the Ukraine economy by $25 \%$. On the positive side, Ukraine has achieved widespread sympathy for its struggle against Russia and governments and international organizations have rallied to its support. Some may think that the largest country on earth with the second largest nuclear weapons stockpile could easily defeat a country with only a population of about 45 million. Indeed, the simple calculation of the military power of the Russia overwhelms [2] but, I argue that contingency factors and their consequences affect both countries but Russia more negatively. Hence the outcome of the conflict is a stalemate.

The paper is organized into five main parts: first, is the introduction; second, the qualitative design and methodology used are described; third, a short theoretical review of the literature streams used as a theoretical basis for the research domain and related proposition; fourth, evidence for the global contingencies of the war for Russia and Ukraine are presented; finally, conclusions are drawn.

\section{Methodology}

This paper uses an explanatory qualitative case study methodology [3] where the researcher departs from a theory widely used in international relations, business strategy and political science literature. The theory is used to guide the collection of secondary information, which is then analyzed by categorization and comparison among the relevant stakeholders as recommended in the research methodology literature [4] [5] [6]. As sources for evidence, I used open source articles, reports and websites. Additional insight was developed by observation during frequent visits to Ukraine. Cross referencing and multiple sources of evidence were used to validate claims where plausible. To control for plausible biases in the data collection, analysis and findings two peers to reviewed earlier drafts of this article and offer critical reviews. As a result, new sources of data were used, the analysis was improved and the discussion, implication and conclusion sections were improved. I owe them much for the constructive feedback. 


\section{Theory and Proposition}

This paper uses the contingency theory approach, which is widely used in the international relations, business strategy, political power and behavioral sciences, to solve the riddle why Russia has not gained a quick victory in the war with Ukraine. Such contingency approach to researching plausible outcomes of conflicts and strategies has been advocated in the literature [7] [8] [9]. The contingency theory's foundational disciplines are biology, political sociology and system theory [10] [11] [12] [13]. The contingency theory presumes the leaders adapt their organization to fit the contextual environment and that they are often limited in their freedom of action because of contextual issues. Thus, they must, to a degree, capitulate to the demands of the contextual environment in their policy formulation [14] [15]. In 1978, Pfeffer, and Salancik, [15] merged contingency and resource theories emphasizing that the value of a resource, such as strategic missiles, is contingent upon the current critical resource demand. This explains why Russia's large military and strategic ballistic missiles are of little value in the fight against Ukraine as Russia needs them to meet other threats. In 1951, Zimmerman [16] supports this view and considers contingencies as environmental factors determining what resources are available, thus what decision can be taken. And in 1956, Sprout and Sprout [17] concurred and added intangible resources to the contingency pool and then in 1957 they emphasized the role of information about the environment and decision maker's thought processes as environmental contingencies for foreign policy decisions. From the contingency theory perspective, I expect that Russia and Ukraine have contingencies with consequences that may limit their freedom of action and act as hindrance or benefit in the war. The preliminary investigation appears to indicate that these contingencies are more favorable to Ukraine than to Russia. Hence, the following proposition is postulated:

Proposition: contingencies and consequences of the war are negatively affecting Russia more than Ukraine.

\section{Global Contingencies and the Consequences of the War for Russia and Ukraine}

Russia's aggression towards Ukraine has not been a smooth sailing for Moscow and the question is what is the riddle? How come a great superpower has not easily and fast overtaken the much smaller Ukraine. I propose several plausible explanations to this riddle below. The explanations are neither supposed to be a complete list of explanations nor the only explanations but, the ones I have mentioned provide a different perspective than commonly expressed in the public media and academic literature reviewed above and they include military, economic, diplomatic and geopolitical contingencies limiting Russia's options in Ukraine. The pro-Russian forces have failed to gain complete control of Donetsk and Lugansk districts and their further advances into Ukraine have been stopped by the Ukrainian forces, which came as a surprise to the Russian generals after 
the easy victory in the Crimea. The fierce resistance by the Ukrainian army, best demonstrated by the 242-day battle for the Donetsk Airport, upset the Russian plans for total domination of the Donbass basin and left the $\$ 860$ million airport in complete ruin. In addition, the Russian military must consider the Ukraine's substantial military capabilities, such as a large conventional weapons stockpile and biological, chemical, nuclear and radiological weapons potential as analyzed by [18].

The economic consequences for the Russian economy have been severe. The Russian ruble has taken a beating on foreign exchange markets and lost 50 percent of its value since January of 2014, partially due to international sanctions over the Ukraine conflict. To add to this problem, Russia suffered a capital flight of $\$ 151$ billion in 2014 and $\$ 114$ billion 2015 with the foreign currency reserves reaching a low of $\$ 356$ billion in May of 2015. Such capital flight cannot be sustained for long and the Russian government responded with a two-prone strategy of limiting capital outflows and encouraging Russians and Russian companies to repatriate capital to Russia. These measures were partially successful and Russia's foreign currency reserves rose to $\$ 418$ billion in late 2017. Still, this is more than $\$ 104$ billion lower than the reserves stood in October 2013 when the Euromaidan protest begun in Kiev [19].

Similarly, Russian trade sanctions on Ukraine have hurt the Russian economy as much needed components for the Russian military industrial complex manufactured in Ukraine has dried up. The Ukrainian components facilitated Russia's export of contracted military equipment such as the AN140 tactical airplane and Mi-38 transport helicopter, the Ka-52 and Mi-28 attack helicopters. These helicopters are designed to use engines made by Ukraine's Motor Sich plant [20]. Also, Ukraine was one of Russia's biggest trade partners before the conflict. For example, Ukraine was the largest buyer of Russian gas as it purchased 60 billion cubic meters of gas in 2012 which dwarfs Germany's purchases of 38 billion cubic meters, the second largest customer for Russian gas. Also, Ukraine was a reliable and cheap supplier of agricultural products to Russia which imported meat, gains, milk, vegetables, fruit and processed food products from Ukraine. Hence the Russian sanctions on Ukraine hurt Russia greatly from an economic point of view and Russia's aspirations for further integration with the European Union appears to be out of the questions [21].

Another blow to the Russian economy was the collapse of price of oil from over $\$ 100$ in 2013 to as low as $\$ 28$ in 2015 and a low $\$ 50$ s in 2017. This must be a great concern for Russia as one half of its export revenue is energy related. The state-run media has alleged that the collapse of the price of oil is engineered by the USA with aid from Saudi Arabia to punish Russia for its interference in Ukraine [22]. Both President Putin and the Rosneft Chief Executive Officer Igor Sechin have echoed those allegations [23] [24]. True or not, President Putin is likely to be aware that it was a similar collapse in oil prices that caused Russia to default on its debt in 1998 and ultimately resulted in the resignation of President Yeltsin. Additional contingencies for Russian decision makers are diplomatic 
isolation, unfavorable world media and the additional sanctions. Particularity, the H.R. 3364 - Countering America's Adversaries Through Sanctions Act of 2017 and H.R. 1644 which will, if passed by the US Senate and signed by the President Trump, put enormous pressure on Russia.

Furthermore, the Russian commitment to the war in Syria is another contingency that puts more demands on Russia's military and economic resources as the end of that war is nowhere in sight. Moreover, the diplomatic and military danger of being in direct conflict with military elements that may be receiving active support from the United States sets the stage for an accidental war with NATO countries. A case in point is the Turkish downing of the Russian fighter airplane on 24/11 2015 is a case in point [25] and the Wall Street Journal reports that Russian airplanes in Syria had bombed a base used by U.S. special forces on the 16 June 2016 only a day after it had been vacated [22]. Likewise, the escalation of tensions on the Korean peninsula prompted Russia to move additional military forces to the North Korean boarder further reducing the military forces available for the Ukraine war. And, Kim Jong Un's threat to fire missiles at Guam on August 15, 2017 raised the risk of war in the Pacific to crisis level leading to further dispersal of Russian military resources, thus, limiting the military resources available to fight the war with Ukraine. Although the acquisition of Crimea was well received by the Russian public and raised President Putin's approval rating, a total war with the brothers in Ukraine is unlikely to be well received by the Russian public concerned about multiple threats to world security. Next, I will discuss the consequence of the war for Ukraine.

There is significant evidence Russia's war with Ukraine, employing hybrid tactics, is having a significant negative impact on Ukraine. The Ukraine currency has collapsed in value; in the first two months of 2015, the Ukraine currency lost $40 \%$ of its value prompting international rating services to downgrade the country's sovereign debt to Ca, which means an imminent risk of default [26] [27]. Ukraine has de facto defaulted on its sovereign foreign debt, the GDP has declined by as much as a quarter, hyperinflation has doubled the price of basic food, while electricity, water and gas prices rose 553\% in 2015 [28]. The Crimea is lost and the critical Donbass basin, one of the key industrial engines of the Ukrainian economy, is lost or devastated. Sixty-five coal mines have been lost resulting in severe coal shortages for the coal fired electricity plants, which produce $38 \%$ of Ukraine's electricity and most of the coal fired district heating plants in major cities. In the fall of 2015, only a two-week supply of coal was in stock and three months' supply of gas was in storage with little signs of further external supplies [29] [30]. How the Kiev government managed to keep the lights and heat on during the 2015/16 and 2016/7 winters is a mystery. The official story, circulated in the Ukrainian media, is that reverse flow of gas from the EU has made up the shortage but, the share volume of gas consumed by Ukraine, which is about twice the total German imports of natural gas from Russia, makes this explanation doubtful. A more likely explanation is that a secret deal has been made where the EU pays for or guarantees the payments for 
Ukrainian gas imports from Russia. The annexation of Crimea and loss of some of the Donbass industries had severe impact on Ukrainian banks because of non-performing loans from these regions. The borrowers from the Ukrainian banks didn't pay their debts but, they collected or transferred their bank balances in the Ukrainian banks. More than 20 Ukrainian banks went into liquidation or receivership in the first two years of the crisis [31] [32] and, by 2017 the Ukrainian government owned 55\% of the banking system after the country's largest bank, Privat Bank, had to be saved by the government. Also, Russia was one of Ukraine's biggest export markets, which has been closed by Russian sanctions and the Ukrainian counter-sanctions. The combined economic shocks of hyperinflation, loss of the Donbass and Crimea, cost of the war in Donbass, export restrictions to Russia, banking crisis and the collapse in the value of the Ukraine hryvnia have devastated the Ukrainian economy.

On the diplomatic front, Russia has scored significant victories with the Minsk 1 and Minsk 2 agreements, which stipulated semi-autonomous status for Lugansk and Donetsk regions as this was a de facto capitulation by the Poroshenko government. Although, Russian information warfare tactics attempt to undermine the support for the Kiev government both in Ukraine and worldwide, the Ukraine's government survived a no-confidence vote on 16 February 2016. However, the Ukrainian Prime Minister Arseniy Yatsenyuk resigned on the 10 April 2016 because of corruption allegations. His resignation may have strengthened the position of President Poroshenko and may ultimately lead to more unified and effective government in Ukraine. This dire situation in Ukraine is partially offset by favorable world media and help from the EU, USA, IMF and other international institutions. This includes a $40 \$$ billion IMF bailout package negotiated in late 2015, which is to be implemented in tranches coinciding with the implementation of economic and governance reforms by the Ukraine government.

Moreover, the armed forces of Ukraine have gained moral and material support from abroad. An Ukrainian-Polish-Lithuanian brigade has been established and negotiations are underway to establish a Ukraine, Romania and Bulgaria joint brigade [33]. NATO has given Ukraine a comprehensive package of aid in the security and defense sector [34] and, Ukraine has received material support and training from the USA and UK. Canada has chipped in and it is providing military training to the Ukraine army and, the two countries have signed a free trade agreement. Additionally, the Ukraine armed forces co-operation and competence was strengthened by co-hosting the $17^{\text {th }}$ Sea Breeze fleet exercises in the Black Sea in July 2017, in which 17 NATO nations participated. The co-hosting of the all arms exercises by the USA and Ukraine is a clear indication of the commitment NATO has made to the defense of Ukraine [35].

Even with intense efforts by Russia, Ukraine survived the annexation of Crimea and the military onslaught on the Donbass and fought the military situation to a stalemate and, after more than three years of conflict, Ukraine has not collapsed into the Russia's hands. 


\section{Conclusion}

The evidence supports the proposition that Ukraine has more contingency factors in its favor than Russia. Hence the answer to the riddle why Russia has not waged a total war on Ukraine and conquered Kiev is that external and internal contingency factors, such as economic, diplomatic and geopolitical contingencies, have limited Russia's actions. Furthermore, the plausibility of Russia waging a total war on the Ukraine is unlikely to happened because, of the Ukraine military's defense capability and NATO and US support. Moreover, it appears that the tide of public and government opinion in Ukraine and western countries is so persuasively against Russia that the opportunity for Russia to influence events in Ukraine by non-violent means is going to be very limited for the foreseeable future. The world opinion is favorable towards Ukraine's struggle for its independence, the armed forces of Ukraine are fully mobilized, Ukraine has a government and military that has gained legitimacy via elections, the surrounding countries, such as Poland and the Baltic states have mobilized and generally NATO has built up its forces on Russia's borders. The EU, IMF and World Bank, as well as, many European governments have committed to Ukraine. Consequently, the contingency factors negatively affecting Russia have grown since the conflict started and this has benefited Ukraine and, Russia's opportunity to take Kiev by military means is lost.

\section{References}

[1] Huggler, J. (2014) Putin "Privately Threatened to Invade Poland, Romania and the Baltic States" Quoted by the Telegraph 18 September 2014.

http://www.telegraph.co.uk/news/worldnews/europe/russia/11106195/Putin-private ly-threatened-to-invade-Poland-Romania-and-the-Baltic-states.html

[2] Clowes, D. and Choroś-Mrozowska, D. (2015) Aspects of Global Security-The Measurement of Power \& Its Projection. Results from Twenty Selected Countries (2000-2013). Journal of International Studies, 8, 53-66. https://doi.org/10.14254/2071-8330.2015/8-1/5

[3] Yin, R.K. (1981) The Case Study Crisis: Some Answers. Administrative Science Quarterly, 26, 58-65. https://doi.org/10.2307/2392599

[4] Yin, R.K. (2013) Case Study Research: Design and Methods. Sage Publications, London.

[5] Ferrier, W.J. (2001) Navigating the Competitive Landscape: The Drivers and Consequences of Competitive Aggressiveness. Academy of Management Journal, 44, 858-877. https://doi.org/10.2307/3069419

[6] Levy, J.S. (2008) Case Studies: Types, Designs, and Logics of Inference.

[7] Baldwin, D.A. (2012) Power and International Relations. Handbook of International Relations. Sage, London, 177-191.

[8] Barnett, M. and Duvall, R. (2005) Power in International Politics. International Organization, 59, 39-75. https://doi.org/10.1017/S0020818305050010

[9] Wohlforth, W.C., Little, R., Kaufman, S.J., et al. (2007) Testing Balance-of-Power Theory in World History. European Journal of International Relations, 13, 155-185. https://doi.org/10.1177/1354066107076951 
[10] Sprout, H. and Sprout, M. (1957) Environment Factors in the Study of International Politics. Journal of Conflict Resolution, 1, 309-328. https://doi.org/10.1177/002200275700100401

[11] Pugh, D.S., et al. (1963) A Conceptual Scheme for Organizational Analysis. Administrative Science Quarterly, 8, 289-315. https://doi.org/10.2307/2390971

[12] Hannan, M.T. and Freeman, J. (1977) The Population Ecology of Organizations. American Journal of Sociology, 82, 929-964. https://doi.org/10.1086/226424

[13] Lawrence, P. and Lorsch, J. (1967) Differentiation and Integration in Complex Organizations. Administrative Science Quarterly, 12, 1-30. https://doi.org/10.2307/2391211

[14] Lasswell, H.D. and Kaplan, A. (1950) Power and Society: A Framework for Political Inquiry. Yale University Press, New Haven, 75.

[15] Pfeffer, J. and Salancik, G. (1978) The External Control of Organizations: A Resource Dependence Perspective. Harper and Row, New York.

[16] Zimmermann, E.W. (1951) World Resources and Industries. Reversed Edition, Harper and Bros, New York.

[17] Sprout, H. and Sprout, M. (1956) Manmilieu Relationship Hypotheses in the Context of International Politics. Center for International Studies, Princeton University, Boston.

[18] Johannesson, J. (2017) Russia-Ukraine Balance of Military Power. International Studies, 10, 63-73.

[19] Central Bank of the Russian Federation (CBR) (2017) International Reserves of the Russian Federation. http://www.cbr.ru/eng/hd_base/default.aspx?Prtid=mrrf_m

[20] Litovkin, N. (2016) Russia Launches New Engine Production for Military Helicopters. UPI.

http://www.upi.com/Business_News/Security-Industry/2016/06/24/Russia-launches -new-engine-production-for-military-helicopters/9541466775160/

[21] Johannesson, J., Palona, I., Salazar Guillen, J.F. and Fock, M. (2012) UK, Russia, Kazakhstan and Cyprus Governance Compared. Corporate Governance: The International Journal of Business in Society, 12, 226-242.

https://doi.org/10.1108/14720701211214106

[22] Entous, A. and Barnes, J.E. (2015) Deal with Saudis Paved Way for Syrian Airstrikes. Talks with Saudi Arabia Were Linchpin in U.S. Efforts to Get Arab States into Fight against Islamic State. Wall Street Journal, 24 September 2014.

http://www.wsj.com/articles/deal-with-saudis-paved-way-for-syrian-airstrikes-1411 605329

[23] Sheppard, D. and Bousso, R. (2015) Putin's Oil Tsar Slams OPEC and U.S. Launches Broadside at Price Crash. Reuters, February 10, 2015.

http://www.reuters.com/article/2015/02/10/us-rosneft-sechin-oil-idUSKBN0LE1652 $\underline{0150210}$

[24] Putin, V. (2014) Press Conference. Published in News, Transcripts, December 18, 2014. http://en.kremlin.ru/events/president/news/47250

[25] Karadeniz, T. and Kiselyova, M. (2015) Turkey downs Russian Warplane near Syria border, Putin Warns of "Serious Consequences". Reuters, 24/11 2015.

http://www.reuters.com/article/us-mideast-crisis-syria-turkey-idUSKBN0TD0IR20 $\underline{151124}$

[26] Moody's (2015) Rating Action: Moody's Downgrades Ukraine's Sovereign Ratings to Ca; Outlook Remains Negative. Global Credit Research 24 March 2015. 
https://www.moodys.com/research/--PR_320764

[27] Olearchyk, R. (2015) War-Torn Ukraine's Currency Collapses. Financial Times, February 5, 2015.

http://www.ft.com/intl/cms/s/0/7f8f36c4-ad49-11e4-bfcf-00144feab7de.html\#axzz3 m56S4BNY

[28] Klikushin, M. (2015) Ukraine Spirals into the Abyss: Pensioner Suicides and Open Talk of Default. Observer: International Observer News. 23 July 2015.

http://observer.com/2015/07/ukraine-spirals-into-the-abyss-pensioner-suicides-and -open-talk-of-default/

[29] Varfolomeyev, O. (2015) Ukraine Runs Out of Coal, May Run Out of Gas. Eurasia Daily Monitor, Vol. 12, No. 148.

[30] EUROCOAL (2015) Ukraine. http://www.euracoal.com/pages/layout1sp.php?idpage=269

[31] National Bank of Ukraine (NBU) (2015) Reorganization and Liquidation. http://www.bank.gov.ua/control/en/publish/category?cat_id=21616430

[32] Moody's (2015) Rating Action: Moody's Takes Rating Actions on 9 Ukrainian Banks and One Leasing Company. Global Credit Research 26 March 2015.

https://www.moodys.com/research/Moodys-takes-rating-actions-on-9-Ukrainian-b anks-and-one--PR_321631

[33] President of Ukraine (PoU) (2016) Meeting between Presidents of Ukraine and Romania: Ukraine, Romania and Bulgaria Discuss Opportunity to Create Joint Brigade.

http://www.president.gov.ua/en/news/ukrayina-rumuniya-ta-bolgariya-obgovoryuy ut-mozhlivist-stvor-37014

[34] President of Ukraine (PoU) (2016) Ukraine-NATO Commission: Ukraine and NATO Enhance Cooperation. Complex Package of Aid in Security and Defense Sector Has Been Approved.

http://www.president.gov.ua/en/news/komisiya-ukrayina-nato-ukrayina-ta-alyanspogliblyuyut-spivp-37607

[35] US $6^{\text {th }}$ Fleet (2017) Sea Breeze. http://www.c6f.navy.mil/forces-efforts/sea-breeze 